Yayın Geliş Tarihi: 26.01.2016

Yayına Kabul Tarihi: 13.07.2016

Online Yayın Tarihi: 30.09 .2016

http://dx.doi.org/10.16953/deusbed.18349
Dokuz Eylül Üniversitesi

Sosyal Bilimler Enstitüsü Dergisi

Cilt: 18, Say1: 3, Y11: 2016, Sayfa: 409-426

ISSN: 1302-3284 E-ISSN: 1308-0911

Araştırma Makalesi

\title{
SOSYAL BÜTÇELEME TÜRÜ OLARAK ÇOCUKLARA YÖNELIKK BÜTÇELEME ANLAYIŞI VE ÇEŞITLİ ÜLKE UYGULAMALARI
}

\author{
Ahmet ÖZEN* \\ Abdullah Burhan BAHÇE ${ }^{* *}$ \\ Ferhat AKBEY ${ }^{* * *}$
}

\begin{abstract}
$\ddot{O} z$
Sosyal bir devlet niteliğine sahip olmak; toplumsal dĕgerlere duyarl ve vatandaşlartyla sinerji oluşturmuş demokratik yönetimlerin öncelikli amaçlarından biridir. Bu amaca ulaşma yolunda ciddi mesafeler almış ülkelerde insani gelişme düzeylerinin de oldukça yüksek olduğu kabul edilir. Bir ülkenin insani gelişmişlik düzeyinde arzuladiğ hedeflere ulaşabilmesi için en önemli mali politika aracı ise bütçedir. Elbette devlet bütçelerinin bu amaca yönelik kullanılabilmesi açısından bazı özelliklere sahip olması gereklidir. Bu özellikler arasında bütçeye sosyal bütçeleme anlayışının ve bunu destekleyici çocuklara yönelik bütçe anlayışının dâhil edilmesi yer almaktadır. Geleceğin yetişkinleri olarak nitelendirebileceğimiz bugünün çocuklarına yönelik politikaların insani gelişme hedefinde önemli bir aşama olduğunu belirtmek gerekmektedir. Özellikle toplumsal gelişme arzusunda olan ve daha üst seviyelerde yer almak isteyen ülkeler bu tür bütçeleme anlayışına uygun adımlar atmaktadır. Nitekim bu çalışmada sosyal bütçeleme ve buna uygun çocuk bütçeleme kavramları ele alınmış ve çocuklara yönelik bütçeleme anlayışına uygun çeşitli ülke örnekleri üzerinde durulmuştur. Bu tür uygulamaların ele alınmasinın kalkınma hedefine ulaşma açısından karar alıcılara yol gösterici olacă̆ değerlendirilmektedir.
\end{abstract}

Anahtar Kelimeler: Devlet Bütçesi, Sosyal Bütçeleme, Çocuk Bütçeleme.

\section{CHILD BUDGETING APPROACH AS A SOCIAL BUDGETING TYPE WITH SOME COUNTRY EXAMPLES}

\author{
Abstract \\ To have a social government characteristic is one of the primarily aims for \\ democratic states which are sensible to public values and bring synergy with the society. It

\footnotetext{
* Doç. Dr., Dokuz Eylül Üniversitesi, İktisadi ve İdari Bilimler Fakültesi, Maliye Bölümü, ahmet.ozen@deu.edu.tr

**Yrd. Doç. Dr., Dumlupınar Üniversitesi, İktisadi ve İdari Bilimler Fakültesi, Maliye Bölümü, abdullah.bahce@dpu.edu.tr

${ }^{* * *}$ Yrd. Doç. Dr., Erciyes Üniversitesi, İktisadi ve İdari Bilimler Fakültesi, Maliye Bölümü, ferhatakbey@erciyes.edu.tr
} 
can be said that human development level is high in the countries that have made important progress on this aim. The main public policy tool is the government budget for a country that has a high level of human development target. The public budget has to have some characteristics to achieve this target. Having a social budgeting approach and child budgeting approach to support it are a few of those characteristics. It can be initially emphasized that the social politics for children, who are adults of the future, will provide the main turning point for human development purpose. Especially countries that want to reach at a high level of human development, make progress for this kind of budgeting. Thus, social budgeting and child budgeting approaches are evaluated, and selected countries' child budget applications are examined. It will be helpful to deal with these kinds of applications for policy makers to reach their development goals.

Keywords: Public Budgeting, Social Budgeting, Child Budgeting.

\section{GíRis}

Kamu bütçesi, devletin gelecek döneme ilişkin politikalarının şekillendirildiği temel metin olarak ifade edilen ve bu yönüyle toplumun geleceğinin şekillendirilmesinde temel rol oynayan yasal bir belge olarak nitelendirilmektedir. Bir devlet, kendi bütçesi ile toplumsal anlamda faydayı en fazla kılacak hizmetleri sunma arzusu taşımalıdır. Bu anlamda devlet; toplumun her kesiminin ortak veya münferit gereksinimlerine uygun olarak bir devlet bütçesi hazırlayabilmelidir.

Bir devletin sosyal yapının geliştirilmesi amacıyla sosyal harcamalara önem vermesi literatürde sosyal bütçeleme kavramını ön plana çıkarmıştır. Sosyal bütçe anlayışının yöneldiği kesimlerden biri de çocuklar olup, çocuklar, ortak özellikleri bulunmayan yani homojen olmayan ve yaşamlarında çeşitli risklerle karşılaşan bir grubu temsil etmektedirler. 0-18 yaş arasını kapsayan bu grubun bütünü için aynı anda ortak ihtiyaçlar bulunmayabilir. Çocuk olarak nitelendirilen ve toplumun önemli bir parçasını oluşturan bireyler, özelikle kamusal kaynakların kullanılması konusunda doğrudan söz hakkı olmayan ve bu yönüyle korunmaya muhtaç bir kesimi de nitelendirmektedir.

Çocuklar siyasal karar alma sürecinde ne seçmen, karar alıcı, uygulayıcı ne de baskı veya çıkar grubu olarak doğrudan yer alabilmektedir. Nitekim bu grubun bütçe hazırlık sürecine de doğrudan katılımları söz konusu olmadığı gibi, özellikle sık1 bütçe kesintileri gerektiği zaman öncelikle bu kesime yönelik hizmetlerde kesinti olabilmektedir. Ayrıca çocukların hükümet nezdinde lobicilik faaliyeti yapma şanslarının olduğundan da söz etmek pek mümkün değildir.

Çocuk hakları ve bu konuda devletler nezdinde farkındalığın oluşturulması için Birleşmiş Milletler tarafından 1989 yılında önemli bir adım atılmış ve çocuk haklarının belirlenmesine yönelik Birleşmiş Milletler Çocuk Hakları Sözleşmesi (The United Nations Convention On The Rights Of The Child)'i kabul edilmiştir. $\mathrm{Bu}$ sözleşme uyarınca her çocuğun uygun yaşam koşullarına sahip olma, kaliteli sağlık ve eğitim hizmeti alma şansına sahip olma hakkı bulunmaktadır. İşte bu 
noktada her devletin kendi vatandaşlarına yönelik politikalarını uygulayabilmeleri önem arz etmekte ve sosyal bütçe anlayışına uygun çocuk bütçelerine yer vermeleri gerekli olabilmektedir.

\section{SOSYAL BÜTÇELEME ANLAYIŞININ TEORİK ÇERÇEVESI}

Gelişmişlik düzeylerine göre ülkeler, milli gelirlerinin yüzde 5 ile 30 arasında değişen bir bölümünü sosyal güvenlik sistemleri aracılığıyla sosyal harcamalar biçiminde yeniden dağıtırlar. $\mathrm{Bu}$ sistemlerin tamamı birer yeniden dağıtım sistemidirler ve bu yeniden dağıtım, ülke içerisindeki gelir dağılımını da ciddi biçimde etkilemektedir. Bu çerçevede halen gelir üretim süreçlerinde yer almayan veya hiç almamış vatandaşlarla diğerleri arasındaki gelir ve refah uçurumlarının negatif etkileri sosyal güvenlik sistemleriyle hafifletilmeye çalışılmakta; ayrıca bu sistemler bu yoldan sosyal barışa da katkıda bulundukları için, faktör üretkenliğini artırarak kalkınmaya da katkıda bulunmaktadırlar. İşte sosyal bütçeleme bu süreçlerin en güçlü araçlarından biridir. Sosyal bütçeleme bu açıdan, sosyal politika ile ulusal mali planlama arasında hassasiyeti giderek artan bir keşişim kümesinde siyasal karar alma süreçlerini desteklemektedir (Scholz vd., 2000: 6-7). Sosyal bütçeleme bu bağlamda sosyal güvenlik sistemlerinin bütçelerinin de üzerinde, bunları da içerecek biçimde yapılandırılmış sosyal politika süreçlerini işaret etmektedir.

Sosyal bütçe, gelir yönünden sosyal harcamaları finanse eden tüm gelir kalemlerini içermektedir. Harcamalar yönünden ise istihdam bazlı sosyal güvenlik harcamalarını (emekli maaşları, sağlık giderleri ve işsizlik ödemeleri), kamu sektörünce finanse edilen sosyal koruma harcamalarını (aile geçim indirimleri, sağlık giderleri, sosyal destek, çocuk kaynaklı vergi kolaylıkları) ve sosyal koruma konusundaki kolektif özel sektör işbirliği anlaşmalarını (mesleki emeklilik ödemeleri, diğer firma bazlı sosyal ödemeler) içermektedir (Scholz vd., 2000: 5). $\mathrm{Bu}$ bağlamda sosyal bütçelemenin iki temel yapıtaşından oluştuğunu söyleyebiliriz. Bunlardan ilki ülkenin sosyal güvenlik sisteminin yıllar itibariyle gelir ve giderlerini ifade eden istatistiksel temeldir ki buna "Sosyal Muhasebe Sistemi" (SMS) diyoruz. İkincisi ise orta vadeli bir harcama yapısında, alternatif ekonomik, demografik veya yasal varsayımlar altında sosyal harcama ve gelir simülasyonlarını ifade eden tahminlerdir ki buna da "Sosyal Bütçe" diyoruz (Cichon vd., 2001: 194). Demek ki sosyal bütçelemeyi basit bir biçimde sosyal transferlerin arttırılması şeklinde algılamak eksik bir yaklaşım olacaktır. Bu açıdan sosyal bütçeleme, sosyal politika üretim sürecinden başlayıp, bütçeleme süreçlerine aktif katılımın sağlandığı, bütçe uygulama sonuçlarının toplumsal olarak (sivil toplumun katılımıyla) izlendiği ve denetlendiği; gelir, gider ve borçlanma boyutları olan çok yönlü ve çok süreçli bir sisteme işaret etmektedir.

Ancak burada dikkat edilmesi gereken husus, sosyal bütçelemenin basit bir şekilde kaynak tahsisi ile ilgili olmadığı, bütün bir bütçe döngüsü sürecini 
Özen O., Bahçe, A. B., Akbey, F.

DË̈ SBE Dergisi, Cilt: 18, Sayl: 3

kapsadığıdır (Deles vd., 2010: 8).Sosyal bütçeleme, toplumsal ayrımcılık ve dışlamayla karşı karşıya kalanlar dahil olmak üzere, ülke nüfusunun tamamının haklarını da içerecek şekilde, toplumun hedef ve önceliklerinin daha iyi yansıtıldığg 1 -başta devlet bütçesi olmak üzere- kamusal politika oluşturma süreçlerini ifade eder. Burada sosyal bütçeleme ile "sosyal bütçe" arasındaki farkı da belirtmek gerekmektedir. Sosyal bütçe, bütçede yer alan kaynağın, sosyal sektörler (eğitim, sağlık, sosyal koruma vs.) arasında ne şekilde dağıtıldığını ifade eder (Doytch vd., 2010: 2). Oysa sosyal bütçeleme, toplumsal kesimlerin haklarını korumaya ve refahını geliştirmeye yönelik uzun soluklu politikaların oluşturulma ve uygulama süreçleriyle ilgilidir. Özetle, sosyal bütçeleme "süreç", sosyal bütçe ise "sonuç"tur.

Sosyal bütçeleme bu açıdan, toplumun önceliklerinin tüm kamusal politikalara ve bunların yansıdığı temel mali araç olan bütçeleme süreçlerine yansımasıdır. Bu yansımanın daha sağlıklı gerçekleşebilmesi için de, bütçeleme süreçlerinde bazı ilkelere uyulması gerekmektedir. UNICEF (Doytch vd., 2010: 23), bu ilkeleri şu şekilde sıralamaktadır:

\section{- Maksimum Ulaşılabilir Kaynak}

Çocukların [kadınların ve yoksul ailelerin] yiyecek, sağlık, eğitim ve diğer haklarının kamu maliyesi aracıllğıyla geliştirilmesine yönelik olarak maksimum kaynağın bu alana kanalize edilmesi gerekmektedir. edilmelidir:

Elbette bu süreçte aşağıdaki temel kamu maliyesi ilkelerine de riayet

\section{- Eşitlik}

Devlet bütçesi ayrımcı olmamaya, toplumsal katılıma ve toplumdaki güç ilişkilerine karşı farkındalığa dikkat etmelidir. Bu bağlamda; çocuklar, kadınlar ve yoksul aileler; gerçek kamusal kaynak tahsisi ve karar alma süreçlerinde dışarıda tutulmamalıdır.

Bir ülkede yaşayan tüm vatandaşların her alanda birbirine eşit olduğu ve eşit koşullar altında her bir bireye eşit muamele edildiği bir düzenin varlığ demokrasinin olmazsa olmaz şartlarından birini ifade etmektedir. Bu bağlamda günümüzde demokrasi yönetim biçimini benimseyen ülkelerin politik, sosyal ve kültürel yaşamlarını biçimlendiren en temel ilke "eşitlik ilkesi" olarak görülmektedir. (Erkan vd., 2012: 92).

\section{- Verimlilik}

Sosyal bütçeleme süreçleri, gelirleri arttırırken, kaynakları dağıtırken ve bunların sonuçlarını elde ederken mümkün olan en az tahrifata ve maliyete sebebiyet vererek gerçekleştirilmelidir. 


\section{- İstikrar}

Sosyal bütçelemeye yönelik kararlar, özellikle ekonominin kırılgan olduğu dönemler boyunca, sürdürülebilir ve uzun dönemli hedefleri desteklemeli, yoksul dostu ve stabil (ekonomideki döngülerden etkilenmeyen) politikaları yansıtmalı ve yeterli sosyal korumayı sağlamalıdır.

\section{- Katılım ve Hesap Verebilirlik}

Katılımcı karar alma süreçleri, tüm toplum kesimlerinden herkesin söz söyleme hakkının teslim edilmesini sağlar. Bunun dışında, kamu maliyesi "şeffaf" süreçlerle desteklenerek, kamuoyuna bütçe hakkında en geniş yaygınlık düzeyinde bilgi sunulmasını ve halkın proaktif katılımını sağlamalıdır.

Katılım ve hesap verilebilirlik süreçlerinin oluşması için yalnızca bütçe gerçekleşmelerinin açıklanması veya devlet kurumlarının iyi niyeti elbette ki yetersiz olacaktır. Burada sivil toplum örgütleri ile medyaya da önemli görevler düşmektedir. Sivil toplum örgütleri hizmetlerin yetersizliği ve kalitesinin düşüklügü konusunda deliller ortaya koymalı; medya organları ise sürekli olarak eğitim-öğretime ayrılan kaynağın yetersizliğini kayda geçirmelidir. Böylelikle, sosyal bütçeleme süreçlerinde yer alan parlamenterlerin daha fazla ödenek talep ederken elleri güçlenmiş olacaktır (Doytch vd., 2010: 8).

Elbette burada karar alma süreçlerinin yukarıdaki ilkelere uygun gerçekleşmesinin yanı sıra, bu kararların ne şekilde yapılandırıldığı ve yönetildiği de önem kazanmaktadır. Örneğin, merkezden taşraya kaynak transferlerinin, ülke içi coğrafi eşitsizlikleri gidermede etkin bir yöntem olduğuna yönelik yaygın bir kanaat mevcuttur. Oysa çalışmalar bu tür önyargıların geçersiz olduğunu ortaya koymaktadır. Mesela eğitim alanında 2000'li yılların başında gerçekleştirilen transferler, Tayland'da eğitime ulaşmada gelir grupları arasındaki eşitsizliği ortadan kaldırmamışken, Endonezya'da benzer adem-i merkezileştirme süreci olumlu sonuç vermiş ve eğitime ulaşmada görülen dengesizlikler önemli oranda giderilmiştir (Doytch vd., 2010: 5). Demek ki, politika oluşturmak mesele değildir. Asıl mesele sosyal politikaların ve bütçenin hedefe ulaşacak tarzda uygulanması ve sonuç alınmasıdır. Yani politika ve bütçenin oluşturulması yeterli olmamakta, bütçenin yönetilmesi de ayrı önem kazanmaktadır. Tabi kültürel ve antropolojik farkl11ıkların da göz önünde bulundurulması gerekmektedir.

Benzer şekilde, ekonomideki dalgalanmaların sosyal bütçeleme ve harcamalara yansıması konusunda genel bir eğilim yoktur. Yani durgunluk veya resesyon dönemlerinde sosyal harcamalarda mutlaka bir azalma veya artış görüleceğine yönelik bir veri mevcut değildir. Ancak teorisyenlerin genel kanaati, böyle dönemlerde sosyal bütçeleme süreçleri üzerinde ciddi basınçların oluşacağ 1 yönündedir. Ortiz vd.'nin tespitine göre ekonomik krizlerden sonra, sosyal bütçeleme üzerinde basınç oluşturduğu görülen en yaygın önlemler maaşlarda kesintiye gidilmesi, sosyal yardımlara sinırlama getirilmesi ve sosyal korumaya yönelik transferlerde yeniden yapılanmaya gidilmesidir (Ortiz vd., 2010: 15, 18). 
Özen O., Bahçe, A. B., Akbey, F. DË̈ SBE Dergisi, Cilt: 18, Sayl: 3

Örneğin 2008 finansal krizi sonrası IMF üyesi 124 ülke içerisinden Hindistan, Kazakistan, Şili, Nijerya, Romanya gibi 56 ülkede maaş kesintilerine gidilmiş; Malezya, Belarus, Mısır, Pakistan ve Meksika'nın da aralarında bulunduğu yine 56 ülkede sosyal yardım ve transferler kısılmış; Moldova, Nepal, Peru, Bulgaristan ve Filipinler dahil 34 ülkede sosyal transferlerde yeniden yapılanmaya gidilmiş; Bosna-Hersek, Jamaika, Lübnan, Nikaragua ve Ukrayna gibi 28 ülkede emekli maaşları reforma tabi tutulmuş; ve Kırgızistan, Rusya, Mısır ve Hindistan'ında aralarında olduğu toplam 53 ülkede ise yoksulların yoğun olarak tükettiği ürünler üzerindeki harcama vergileri arttırılmıştır (Ortiz vd., 2011a: 1314). Görüldügü gibi, bir yandan krizin yoksullar üzerindeki etkilerinin asgari düzeyde tutulması için tedbirler alınması gereği önem kazanırken, diğer yandan ironik bir biçimde, bu tedbirler tam da yoksullar üzerinde uygulanabilmekte ve bu durum da sosyal bütçelemenin mantığ i ile çelişmektedir. İşte toplumsal barışa ciddi tehditler getirecek bu tür durumlarda sosyal bütçeleme ayr1 bir önem kazanmaktadır. $\mathrm{Bu}$ bağlamda, etkin ve istikrarlı sosyal bütçeleme süreçleri, ekonomik çalkantının toplumsal yansımalarını asgari düzeyde tutmanın başat aracı haline gelmektedir

Bu konuda ayrıca uluslararası mali kurumlar da hükumetlere destek vermek için bazı araçlar geliştirmişlerdir. Örneğin 2009 yılında, Asya Kalkınma Bankası bir tür "Anti-konjonktürel Destek Kolaylığı" (Countercyclical Support Facility) ihdas etmiş ve bu fona 3 milyar dolar aktarmıştır. Yine Dünya Bankası, bu tür antikonjonktürel mücadeleler için Kırılganlık Fonunda (Vulnerability Fund) 7 milyar doları hazır tutmuştur. IMF ise sosyal harcamaların aşınmasını hafifletmek üzere borç verme politikasını gözden geçirmiştir (Doytch vd., 2010: 10). Ancak bu kurumların finansal kaynaklarının sinırlı olduğu da unutulmamalıdır. Diğer bir deyişle, sosyal bütçenin finansmanına yönelik olarak kaynak yaratması gereken asıl aktör ulusal hükumetlerin kendileridir. Uluslararası mali kurumların katkısı ancak palyatif ve kısmen de karşılıklı olacaktır.

Asıl sosyal bütçelemenin finansmanına yönelik ülke içi mali önlemler, sosyal politikaların ve bütçelemenin istikrarlı bir yapıya kavuşturulması için katkıda bulunacaktır. Vergi tabanının genişletilmesi ve (eğer uygulanabilir ise) artan oranlı vergi tarifelerinin uygulanmasi; ayrica kamusal israfin ve verimsizliklerin asgari düzeye çekilmesine yönelik önlemler, bu konuda oldukça faydalı olacaktır. Bu önlemlere eşlik edecek biçimde, kamu harcamalarının yeniden önceliklendirilmesi de gerekebilecektir. Bu açıdan, esas sosyal yatırımlara yer açmak üzere, düşük etkili veya etkin olmayan harcamaların daha düşük düzeyde önceliklendirilmesi gerekmektedir. Yine borç stokunun ve çevriminin müsaade ettiği durumlarda borçlanma da iyi bir alternatif olabilecektir. Ayrica merkez bankası döviz rezervlerine başvurmak da bir diğer alternatiftir (Ortiz vd., 2010: 2526; Ortiz vd., 2011b: 43). Uzun dönemli ülke verilerinden hareketle gerçekleştirilen kantitatif çalışmalar göstermektedir ki, ekonomik krizler sonrasında gerçekleştirilen sosyal harcamalar, bir bütün olarak devlet harcamalarıyla karşılaştırıldığında, krizin GSYİH üzerinden gerçekleştirdiği şoku 
(tahribatı) yüzde 16'ya kadar daha fazla hafifletmektedir. Diğer bir ifadeyle, bu harcamalar, konjonktür karşısında adeta bir tür otomatik stabilizatör işlevi görmektedir (Deles vd., 2010: 11). Tahmin edileceği üzere, özellikle talep yetersizliğinden kaynaklanan krizlerden "sağlıklı" bir şekilde çıkabilme yolunda bu tür stabilizatörler hayati önemi haizdir. Çünkü yoksullar toplumun tasarruf meyli düşük olan kesimini oluşturur. $\mathrm{Bu}$ yüzden, gelirlerindeki neredeyse her türlü değişim "harcanabilirdir".

Kaldı ki sosyal harcamalar bir bakıma geleceğe yönelik insan kaynakları yatırımlarıdır. $\mathrm{Bu}$ açıdan gelecekteki iyi eğitilmiş ve sağlıklı nesiller, bugünden verilen bütçe açığını kapatabilecek katma değeri yaratmak için gerekli donanıma sahip olacaklardır. Zaten 30 yıl ve üzeri ülke verilerini ele alan kantitatif çalışmalar da sosyal harcamalardaki artışın, ülkelerin uzun dönem büyümesinde sıçramaya yol açtığını ve yoksulluğu da azalttığını ortaya koymaktadır (Deles vd., 2010: 10). Bu yüzden, sosyal politikalarda ve bütçelemede kullanılmak üzere daha fazla yardım ve transfer yapılmasına yönelik olarak lobi faaliyetinde bulunmak da (Ortiz vd., 2011b: 43) özellikle sosyal politikalardan sorumlu birimlerin üzerinde durmas1 gereken desteklerden biri olacaktır.

Sosyal bütçelemeye yönelik kısa vadede en hızlı tedbirlerden biri olarak kamusal harcamaların yeniden önceliklendirilmesi konusuna biraz değinmekte fayda var. Bütçeye ek gelir sağlanmadığ1 müddetçe bu tür değişiklikler bir süre sonra sıfır toplamlı bir karar sürecine dönüşür. Yani sosyal harcamaları arttırmak için mutlak suretle devletin diğer fonksiyonlarından kaynak kesmek gerekecektir. Normal zamanlarda ilk akla gelen harcama kalemi savunma ve silah harcamaları yani askeri giderlerdir. Çünkü siyasetçiler açısından diğer kalemlerde (sağlık, adalet vs.) kesintiye gitmek oldukça riskli olacaktır. Ekonomik kriz dönemlerinde ise tasarruf tedbirleri kapsamında, genel olarak tüm harcama kalemlerinde kesintiye gidilmekle birlikte, en büyük kaybı sosyal harcamalar yaşamaktadır. Bu açıdan sosyal bütçelemeye istikrar kazandırmak oldukça güç bir iştir. Yapılan analizlerde, son yıllarda giderek yaygınlaşan "Orta Vadeli Harcama Çerçevesi" uygulamalarının, bu eğilimi bir nebze de olsa azalttığını göstermektedir (Deles vd., 2010: 19). Bunun dışında; i) yüksek maliyetli-düşük etkili yatırımlar yerine yüksek etki düzeyine sahip yatırımlara yönelerek (örneğin nükleer santral harcamalarından kesip, yoksul mahallelere elektrik ve kanalizasyon götürmek); ii) Verimsiz devlet faaliyetlerini ortadan kaldırarak; iii) yolsuzlukla ve yozlaşma ile mücadele ederek; sosyal bütçeleme süreçleri mümkün olduğunca güçlendirilebilir (Ortiz vd., 2011b: $5-6)$.

Hükümetler bu tür tedbirleri alırken, sosyal bütçelemenin kapsamı dışındaki kesimlerden gelecek baskılara ve lobicilik faaliyetlerine karşı da dayanıklı olmalıdırlar. Sosyal bütçeleme, ekonomideki her türlü maliyet değişikliğini devlet bütçesinin üstlenmesi anlamına gelmemelidir. Örneğin, Ocak 2016'dan itibaren Türkiye'de asgari ücret düzeyinde bir iyileştirme gerçekleştirilmiştir. Normalde bunun, devlet bütçesi ile doğrudan bir ilişkisi yoktur (artacak sosyal güvenlik 
Özen O., Bahçe, A. B., Akbey, F.

DEÜ SBE Dergisi, Cilt: 18, Sayl: 3

primleri ve gelir vergisi gelirleri açısından dolaylı bir ilişki mevcuttur). Ancak işveren kesiminden gelen baskılar sonucu, ücretlerdeki bu artışın işverene getireceği yükün bir kısmını merkezi yönetim bütçesi üstlenmiştir. Kanaatimizce sosyal bütçeleme bu değildir, daha doğru ifade edecek olursak, sosyal bütçelemenin yöntemi bu değildir.

Elbette sadece sosyal bütçelemeye yönelik tedbirlerin alınması ve uygulanması yeterli olmayacaktır. Bu süreçlerin takibinin ne derece önemli olduğu, yukarıda eğitim harcamaları konusunda verilen Tayland ve Endonezya örneklerinde de açıkça görülmektedir. Buna yönelik olarak, parlamenterler ve sivil toplum işbirliğiyle, sosyal harcamaların etkin bir şekilde gerçekleştirilip gerçekleştirilmediğini düzenli şekilde izlemek üzere "sosyal rasathaneler" (social observatories) tesis edilebilir ve bunlar aracıllğıyla toplum adına "sosyal denetimler" (social audit) gerçekleştirilebilir. Örneğin Malawi'de eğitim bütçesinin uygulanmasını izlemek üzere kurulan ve yerel uygulamalarla merkez eğitim bütçesi uygulamalarını tek merkezden izlemeyi başaran CSCQBE adlı inisiyatif, bu uygulamanın birebir örneğidir. Yine Zimbabwe'de hükumete bağlı Politika Analizi ve Koordinasyon Departmanı doğrudan UNICEF ile birlikte bu gözlem ve denetimleri gerçekleştirmektedir. Filipinler de ise bir adım öteye gidilerek "Alternatif Bütçe İnisiyatifi" (ABİ) adında bir oluşuma gidilmiş ve bütçe süreçlerine sivil toplum örgütlerinin aktif katılımı sağlanmıştır. ABİ, bütçe görüşmelerinde oldukça merkezi bir konuma sahiptir ve önerileri parlamenterler tarafından üst düzey ciddiyetle ele alınmaktadır (Deles vd., 2010: 14-15, 32-33).

Bu tür örnek uygulamalar çoğaldıkça "katılımcı" yönü ağır basan sosyal bütçeleme süreçleri daha sağlıklı bir yapıya kavuşacaktır. Zaten sosyal bütçeleme ancak bu tür "Kamu Mali Yönetişimi”" örnekleri ve orta vadeli harcama yapısının doğru kompozisyona kavuşturulmasıyla mümkün olabilecektir.

Sosyal bütçeleme toplumun en mağdur ve toplumsal dokunun çeperlerinde yer alan kesimlerine yöneliktir. Sosyal bütçeleme esas itibariyle şu üç kesime yöneliktir: Kadınlar, çocuklar ve yoksul aileler. $\mathrm{Bu}$ mağduriyetleri ve dışlanmışlıkları en dramatik yaşayanlar ise elbette ki çocuklardır. Bu açıdan sosyal bütçelemenin odak noktalarından biri de çocuklara yönelik bütçelemedir. Dolayısıyla çalışmanın devamında özellikle çocuk eksenli bütçeleme konuları ele alınacaktır.

\section{ÇOCUKLARA YÖNELIKK BÜTÇELEMENIN KAVRAMSAL BOYUTU}

Çocuklara yönelik bütçeleme anlayışı; çocukları etkileyen ekonomik ve sosyal hedeflere ulaşmak için mevcut devlet bütçelerinin eşitlik, doğruluk, sürdürülebilirlik, saydamlık ve maliyet-etkinlik kriterleri çerçevesinde analiz edilmesini esas alan bir anlayıştır (Pantin vd., 2010: 13). Çocukların temel çıkarlarının önceliklendirildiği ve sosyo-ekonomik hayata entegre edildiği bu anlayışta çocuklar için ayrı bir bütçe hazırlanması gerekli değildir. Ayrı bir bütçe 
hazırlamanın yerine esas olan mevcut kamusal faaliyetlerin çocukların ihtiyaçlarını karşılayıp karşılamadığının değerlendirilmesidir. İşte bu anlayış da bu temel prensip üzerine oturtulmuştur. Dünyada çocuk bütçeleri (child budgets), çocuk bütçeleme (child budgeting), çocuk merkezli bütçeler (child-centric budgets), çocuklar için bütçeleme (Budget For Children), çocuğa duyarlı bütçeleme (child sensitive budgeting) ve çocukların bütçeleri (children's budgets) (Save The Children, 2010: 29) şeklinde ifade edilse dahi bu anlayışın temel amacı çocukların yaşam standartlarında ne tür iyileşmelerin yapılabileceğinin belirlenebilmesidir.

UNICEF tarafindan çocuklara yönelik bütçeleme anlayışı şu şekilde tanımlanmıştır: "Çocuklara yönelik bütçeleme çocuk haklarına yönelik farkındalığ 1 ortaya koymaktadır. Bu tür bütçeleme anlayışının temel amacı çocukların ve diğer korumaya muhtaç grupların kamu harcama sisteminde önceliğinin vurgulanmasını sağlamak olup sistemde kamu harcamalarının çocuklara yönelik nasıl etkiler ortaya koyduğu analiz edilmektedir" (Pantin vd., 2010: 11).

Çocuklara yönelik bütçeleme temelde çocuklar için ne kadarlık kamusal kaynak kullanıldığ 1 konusunu ele almakta olup, kamusal gelirlerin ne kadarlık kısmının çocuklara yönelik hizmetlere tahsis edildiği ve bu doğrultuda ne kadarlık harcama yapıldığı hususları ele alınmaktadır (The African Child Policy Forum, 2011: 3). Bu amaçla devlet bütçesinde çocuklara yönelik analizlere yönelik gerekli veri setinin oluşturulabilmesi gereklidir.

$\mathrm{Bu}$ tür bütçeleme anlayışında iki temel amaç ortaya konulmaktadır. Bunlar; çocuk haklarını savunan sivil toplum kuruluşlarının devletin faaliyetleri hakkında yeterli veriye ulaşabilmesini sağlamak ve siyasilere karar alma sürecinde ihtiyaç duyduklar1 verileri temin edebilmektir (Pantin vd., 2010: 11). Bu tür bütçeleme anlayışından muhtemel sonuçların elde edilebilmesi için bütçe yasası veya diğer yasalarda düzenleme yapılması, bütçeleme sürecinin değiştirilmesi, çocuklara yönelik kaynak tahsisinin arttırılması ve hesap verebilirliği sağlayan denetim mekanizmalarının kurulması önem arz etmektedir (Save The Children, 2010: 58). Nitekim bu amaçla beş temel adım atılmalıdır. Bunlar (Children and Young People Committee, 2009: 29):

- Temel problemin belirlenmesi,

- Hedeflenen sonucun belirlenmesi,

- Hükümet tarafindan sonucun elde edilmesi için ne kadar kaynak ayrılacağının tespiti,

- Ayrılan kaynağın kullanılıp kullanılmadığının takibi,

- Kamu harcamasından beklenen sonuçlar ile mevcut sonuçların etkilerinin değerlendirilmesi.

Çocuklara yönelik bütçelemede etkinliği sağlayabilmesi için mevcut bütçe sisteminde bazı temel özellikler bulunmalıdır. Bunlar (Pantin vd., 2010: 12); 
- Çocukların eğitimi, sağlığı ve korunmasına yönelik kamusal politikalar için kaynak tahsislerinde öncelikli hedefleri ortaya koymak,

- Ayrılan kaynakların çocuklara yönelik politika hedeflerine ne düzeyde katk1 sağlayabildiğini ortaya koyan verileri elde etmek,

- Çocukların bütçeleme sürecine katılımlarını sağlayabilmek,

- Çocuk haklarını korumaya yönelik kurulan sivil toplum kuruluşlarının kapasitelerinin artmasını sağlayabilmek,

- Çocukların temel ihtiyaçlarının giderilmesini ve refah seviyelerinin arttırılmasını sağlamaktır.

Çocuklara yönelik bütçelemeyi uygulayan bir ülkenin şu çıktıları elde etmesi de muhtemeldir (Pantin vd., 2010: 12): etmek,

- Sağlık, eğitim, adalet ve sosyal güvenlik alanında bütçesel verileri elde

- Çocuklara yönelik bütçedeki gelişmeleri ve öncelikleri ortaya koymak,

- Çocuklara yönelik kamu hizmetlerinin geliştirilmesine yönelik görüş ortaya koymak,

- Çocuklara yönelik kamu harcamalarını değerlendirmeye yönelik verileri elde etmek,

- Çocukları etkileyen sektör ve alanlarda sivil toplum kuruluşlarının bütçeleme sürecine katılımlarını sağlamaktır.

Dünyada 2012 yılı itibariyle 7.040.823 kişinin 2.213.677'si 18 yaşından küçük olup, dünyanın yaklaşık \%31,5'inin çocuklardan oluştuğunu ifade etmek mümkündür (UNICEF, 2014: 65). Elbette bu kadar geniş bir kesimin kendine has sorunları ve beklentileri bulunabilir. Nitekim hükümetlerin de mevcut bütçe politikalarında bu hususa dikkat etmeleri ve çocuklara yönelik bütçesel tedbirlere yönelmeleri de gerekmektedir. İşte çocuklara yönelik bütçeleme anlayış1 barındırdığı özellikler ile hükümetlere yol gösterici bir nitelik taşımaktadır.

\section{ÇOCUKLARA YÖNELİK BÜTÇELEMEYE İLIŞKINN ÇEŞITTLİ ÜLKE UYGULAMALARI}

Çocuklara yönelik bütçeleme anlayışı, günümüzde oldukça yaygınlaşmaya başlamıștır. Nitekim Güney Afrika, Hindistan, Galler, Jamaika, Vietnam, Kazakistan ve ABD gibi ülkelerde kısmen hazırlık süreci başlatılmış ve Mozambik, Ekvador ve Brezilya gibi ülkelerde ise sistem aktif olarak uygulanmaya başlanmıştır. $\mathrm{Bu}$ kısımda seçilmiş bazı ülke örnekleri üzerinde durularak uygulamalar hakkında genel bilgilere yer verilecektir.

\section{Amerika Birleşik Devletleri}

ABD'de fakir ve düşük gelirli ailelerde çocuklara yapılan temel yardımlar gelir, sağlık, beslenme, erken bakım ve eğitim ile barınma gibi konularda ön plana 
çıkmaktadır. Buna göre gelir konusunda yapılan yardımlar; Muhtaç Ailelere Yapılan Geçici Yardımlar (TANF), Gelir Vergisi İndirimi (EITC), Devlet Gelir Vergisi İndirimi, Çocuk Vergi İndirimi ve Ek Güvenlik Geliri (SSI) olarak sayılabilmektedir. Sağlık konusunda yapılan yardımlar; Yoksullar İçin Sağlık Yardımı ve Devlet Çocuk Sigortası Programı şeklinde sıralanabilmektedir. Beslenme konusundaki yardımlar; Kadın, Bebek ve Çocuk için Ek Beslenme Programı (WIC), Ek Beslenme Destek Programı (Gıda Pulları) ile Ulusal Okul Öğle Yemeği ve Okul Kahvaltı Programları biçiminde gerçekleşmektedir. Erken Bakım ve Eğitim konusundaki temel yardımlar ise; Çocuk Bakımı Sübvansiyonları ile Çocuk Gelişimi ve Erken Çocuk Gelişimi Programları olarak geliştirilmiştir. Son olarak barınma konusunda Konut Sübvansiyonları ile Konut Hareketlilik Programları ön plana çıkmaktadır (Shore ve Shore, 2009: 7).

ABD'deki KIDS Count Veri Merkezi'nin 2007 yılı tahminlerine göre, ABD'deki her 5 çocuktan 1'inin veya toplam çocuk sayısının \%18'inin yoksulluk içinde yaşamaktadır. Tahmin edilen bu çocuk yoksulluğu rakamı yoksulluk içinde yaşayan çocuk sayısının \%14,7 artarak 12,2 milyondan 13,1 milyona yükselmesi nedeniyle kötüleşen bir eğilimi yansıtmaktadır. ABD'de yoksulluk tehdidi altında yaşayan çocukların gerçek rakamının ise daha fazla olduğundan endişe edilmektedir. KIDS Count Merkezi göstergeleri aileleri ve çocukları yoksulluktan kurtaracak ve onlara daha büyük bir ekonomik güvenliğe doğru hareket etmelerinde yardım edecek önlemleri belirlemiştir. Bunlar (Pantin vd., 2010: 1213):

- Çocuk yoksulluğunu azaltacak politik iradeyi kurmak,

- Çalışma programlarını oluşturmak,

Düşük gelirli ailelerin kazandıklarından daha fazlasını ellerinde tutmalarına yardımcı olmaktır. Bu yöndeki düzenlemeler bu şartlar altındaki tüm çocuklara gıda pulu verilmesi, aynı durumdaki tüm çocukların sağlık sigortası güvencesi altına alınması ve işsizlik sigortasının kapsamının genişletilmesi gibi faaliyetleri kapsamaktadır (Pantin vd., 2010: 12).

ABD'de birçok fakir ve düşük gelirli ailelerin devlet desteği aldığı, ancak hala bu ailelerin ve çocuklarının yaşamlarını sürdürebilmek için mücadele etmek zorunda kaldıkları görülmektedir. ABD'de özellikle destek ve yardımlara muhtaç birçok ailenin bu yardımlardan faydalanmadıkları söylenebilir. Bunun temel nedeni; kimi durumda ailelerin yeterli ve doğru bilgiye sahip olmamaları ve özellikle göçmenlerin bilgilendirilmesinde yaşanan İngilizce kılavuzların anlaşılmasındaki zorluktur. Bununla birlikte ABD'de aile ve çocuk yardımlarına yönelik kayıt işlemlerini düzgün yürüten Indiana, Massachusetts ve Oklahoma gibi eyaletlerde fakir ve düşük gelirli ailelerin bu programlara katılımlarının arttı̆g 1 gözlemlenmiştir. ABD'deki deneyimler yardıma muhtaç birçok ailenin; kayıt bürolarında çalışan memurlardan kötü muamele göreceği korkusuyla ya da bu tür programlar vasıtasıyla damgalanmış olma çekincesiyle kayıt olmadı̆̆ını göstermektedir. Kamu destek programları bu şekilde Yoksullar İçin Sağlık Yardımı 
Özen O., Bahçe, A. B., Akbey, F.

DEÜ SBE Dergisi, Cilt: 18, Sayl: 3

ve Gıda Pulları gibi yardımların çalışan aileler de dahil olmak üzere milyonlarca ailenin yaşamında önemli bir rol oynadığını vurgulamaları açısından büyük öneme sahiptir. Devlet dairelerinde sosyal yardımlara ilişkin eğitimlerin de verilmesi gerekmektedir. Düşük gelirli ailelere yardım sağlayan pek çok kuruluşun örgütsel kültürü tamamıyla değişmese de; günümüzde bu kişilere "müşteri” bakış açısıyla hizmet verdiği gözlemlenmektedir. Bunun sonucunda aile ve çocuk yardımlarına ilişkin bazı öneriler şu şekildedir (Pantin vd., 2010: 13):

- Muhtaç durumdaki tüm çocukların gıda pullarından yararlandırılması, ettirilmesi,

- Muhtaç durumdaki tüm çocukların sağlık sigortası programlarına kayıt

- Nafakaların ve çocuk sigortalarının iyileştirilmesi,

- İşsizlik sigortasının iyileştirilmesi,

- Devlet aile politikası ve tıbbi izin politikalarının yürürlüğe konulması,

- Refah yönlendirme programlarının kurulması,

- Düşük gelirli ailelerin tasarruflarını ve mal varlıklarını oluşturmalarına yardımc1 olunması,

- Bireysel Gelişim Hesaplarının genişletilmesi,

- Düşük ücretlilerin kredi erişiminin genişletilmesi.

ABD'de henüz tam anlamıyla çocuklara yönelik bütçeleme anlayışının yerleştiğini söylemek pek mümkün değildir. Bununla birlikte ülkede yoksullara ve özellikle çocuklara yönelik bir dizi sosyal yardım programının yürürlükte bulunduğunu belirtmek gerekir. Bu sürecin devamında çocuklara yönelik çeșitli mali politika tedbirlerinin alınmasının ve bunların bütçe sistemine yerleştirileceğinin de beklentiler dahilinde olduğu söylenebilir.

\section{Ekvador Cumhuriyeti}

Çocuğa duyarlı bütçelemeye ilişkin olarak uygulamacı ülkeler içinde bulunan Ekvador Cumhuriyeti, çocuk bütçelemesini teşvik etmek açısından şu alanları ön planda tutmaktadır (Pantin vd., 2010: 17-18):

\section{Bütçe analizi}

2001 yilında UNICEF, ekonomik koşullar ve bu koşulların çocuklara yansıması hususunu ulusal bütçe üzerine odaklanmak suretiyle analiz etmek için uluslararası ve ulusal danışmanlardan oluşan deneyimli bir ekibi bir araya getirmiştir.

\section{Dünya Bankası müzakereleri}

UNICEF, Dünya Bankası ile müzakerelerde; krediler yerine kamusal fonlarla finanse edilen bir acil yardım programı geliştirmek için Ekvador hükümetini desteklemiştir. Program bu çerçevede okul beslenmesi ve gelir desteği gibi mevcut acil yardım programlarını ve iki yaşın altındaki çocuklar, hamile kadınlar ve emziren anneler için beslenme desteği ile yoksul ailelerin çocuklarını 
okula göndermesi için yardım edilmesi de dâhil olmak üzere yeni girişimleri bünyesinde birleştirmiştir.

\section{Vergi reformu}

UNICEF, Ekvador'un ulusal vergi yapısındaki eşitsizlikleri ve mali kriz dönemlerinde harcama kalıplarını göstermek açısından anlaşı1ır ve oldukça şeffaf olan yayınlar ortaya koymuş ve bu sayede, kamuoyu ile medyanın sosyal adalet hususundaki tartışmalardaki ilgisi yalnızca bütçenin dengelenmesinden ziyade, daha çok vergi reformu hususuna odaklanmıştır.

\section{Diş borç}

UNICEF, öncelikle Ekvador'un Ekonomi ve Maliye Bakanlığı'ndan elde edilen verileri analize tabi tutarak, Ekvador'un borç yükünü değerlendirmiş ve daha sonrasında ise borç geri ödemelerini sosyal yatırımlara dönüştürmek açısından ülkeye imkân sağlamak için, Sosyal Refah Bakanlığı ve uluslararası bir borç erteleme sivil toplum kuruluşu ile birlikte çalışmıştır.

\section{Sosyal harcamaların denetimi}

UNICEF, çocukların ve ergenlerin durumuyla ilgili göstergeleri geliştirmek için, Sosyal Göstergeler Ulusal Bilgi Bankasını desteklemiş; çocukların durumlarını izlemeleri ve hükümete tavsiyede bulunmaları için nüfuz sahibi ve itibarlı vatandaşlardan meydana gelen bir Vatandaş Gözlemevi kurmuş; çocuk haklarının yerel idare düzeyinde denetlenmesini teşvik etmiş ve Ekvador'un yerel toplulukları içerisinde vatandaş temelli gözetim grupları meydana getirmiştir.

Çocuğa duyarlı bütçeleme hususunda UNICEF'in Ekvador'da ortaya koyduğu çabaları bütçe sürecinin hem hükümet görevlileri hem de kamu tarafından daha iyi anlaşılmasını teşvik etmiş ve sürecin daha şeffaf hale gelmesini sağlamıştır. Bu sayede bütçeler ile sosyal adaletin sağlanması arasında anlaşılır ve şeffaf bir bağlantı kurulmuştur. Bu bağlantı sonucunda sosyal ve ekonomik kararalma süreci; 2000 yılında gerçekleştirilen kaynak tahsisi ile karşılaştırıldığında sosyal harcamalarda \%15,5'lik bir artışa neden olmuştur. Bu çerçevede, Ekvador'un daha eşitlikçi kamu harcaması önceliklerine ulaşma potansiyeli araştırılmıştır. Bu bağlamda UNICEF'in çabalarının bir sonucu olarak, Ekvador'un 2000 yılında kişi başı 55 Dolar olan sosyal harcamaları, 2001 yılında Ekvador'un 1996 yılında yaşamış olduğu kriz öncesindeki kişi başı sosyal harcama miktarı olan 86 Dolar seviyesine yaklaşmış ve 83 Dolar olarak gerçekleşmiştir. Toplam harcamanın yüzdesi olarak sosyal harcamalar ele alındığında; 1995 yılından 1999 yılına kadar sosyal harcamaların azaldığı, 2000 yılından itibaren kademeli olarak arttı̆̆ gözlemlenmiştir. Sonuç olarak çocuğa duyarlı bütçeleme hususunda UNICEF'e göre; Ekvador deneyimlerinden öğrenilen en önemli dersin, yaygın bir fikir birliği ve uzlaşmaya dayandığı durumda ve özellikle topluma olumlu bir katkısı olduğu algısı hakimse, ilgili fikri savunan mesajın değişimi teşvik edebileceği şeklinde olduğu ifade edilebilir (Pantin vd., 2010: 18). 
Özen O., Bahçe, A. B., Akbey, F.

DEÜ SBE Dergisi, Cilt: 18 , Sayl: 3

\section{Vietnam}

Vietnam'da çocuk hakları perspektifinde bütçe çalışmaları ihtiyacının farkına varan Save the Children, ülkede çocuk bütçelemesi çalışması yapmak üzere bir araştırma ekibi oluşturmuştur. Araştırma ekibinin gerçekleştirmiş olduğu çalışmada, engelli çocukların eğitimi için eğitim bütçesi ayrılması vurgulanarak bölge düzeyinde ilköğretim için bütçeleme incelenmiştir. Araştırma ekibinin çalışmasında ayrıca, engelli çocuklar için kaynaştırma eğitim sınıflarına sahip olan bazı ilköğretim okullarında bu çocuklar açısından bütçe ve mali kaynakların kullanımı ele alınmıştır (Pantin vd., 2010: 14).

Araştırma ekibinin ortaya koymuş olduğu çalışmada kullanılan temel yaklaşım, bütçelemenin kademeli bir süreç olduğunu göstermiştir. Bu durum bütçe ve mali kaynakların analizinin, bütçenin toplam rasyonalitesi (ekonomideki mali kaynak tahsisinin etkinliği) üzerinde odaklanmadığı, aksine kademeli olarak büyüme rasyonalitesi (bütçenin yıldan yıla değişen kısmı) üzerinde odaklandığ 1 ifade edilmektedir. Araştırma raporunun ortaya koyduğu bu yaklaşımın mantığı, araştırmacıların yanı sıra hükümetlerin bilgi ve verilerin sınırlı erişimi, analiz kabiliyeti ve hatta değerlendirme ve alg1 konularındaki farklılıklar gibi temel sebepler neticesinde çocuklara ilişkin bütçe sorunlarının üstesinden gelemeyecek olabilmeleri sorunudur. Bu nedenle Vietnam'da özellikle merkezi hükümet düzeyinden başlayarak, daha sonrasında ise spesifik bölgeler ve okullar düzeyinde bütçelerin derinlemesine incelenmesi ve gerçekleştirilen inceleme sonucunda hükümetin daha düşük düzeylerinde bütçe sürecinin genel sınırlamalarının anlaşılması sağlanabilecektir (Pantin vd., 2010: 14).

\section{Güney Afrika}

Güney Afrika, çocuk bütçeleme konusunda dikkat çeken ülkelerden biridir. Bu konuda 1995 yılında bir birim kurulmuş olup, bu birim tarafindan devlet bütçesi gözetim altına alınmaya başlanmıştır. Çocuk Bütçesi Birimi (Child Budget Unit)'nin temel amacı, devlet bütçesinin çocuk hakları konusundaki duyarlılığını arttırmak ve gerekli eğitim ve veri toplama faaliyetlerinde bulunmaktır (UNICEF Innocenti Research Centre, 2007: 16).

Birimin yürüttüğü çalışmaların hükümet nezdinde de olumlu katkılar sağlamış olup, bir dizi yeni düzenlemenin yürürlüğe girmesine zemin hazırlamıştır. Örneğin 2001 yılında Çocukların Sosyo-Ekonomik Hakları İçin Bütçeleme: Hükümetin Sorumlulukları ve Sosyal Güvenlik ve Eğitime Yönelik Çocuk Hakları (Budgeting For Child Socio-Economic Rights: Government Obligations And The Child's Right To Social Security And Education) çalışması ile Birim, sosyal yardım alan çocuklarda yaş limitinin 6 yaştan 14'e çıkarılmasını önermiş ve bu öneri Hükümet nezdinde kabul görmüştür. Böylece ülkede 2003-2004 y1lı bütçesiyle birlikte çocuklara yönelik sosyal yardım üst sınır 14'e yükseltilmiştir (Save The Children, 2010: 61). 


\section{Hindistan}

Çocuk bütçeleme konusunda önemli mesafeler kateden ülkelerden biri de Hindistan'dır. Yoksulluğun yoğun olduğu ve çocuk işçiliğin yaygın olduğu ülkede çocuk haklarında yaşanan ihlalleri önlemek ve çocukların yaşam seviyelerini olumlu desteklemek üzere 2001 yılında Çocuk Hakları Merkezi (Centre For Child Rights-HAQ) kurulmuştur. Merkez tarafından bir dizi çalışma yürütülmekte olup merkeze siyasal destek de sağlanmaktadır. Merkezin yürüttüğü faaliyetler neticesinde devlet bütçesi açısından da önemli adımlar atılmıştır. Bu adımlar arasında 2005 yılında hazırlanmış olan Çocuklara Yönelik Ulusal Eylem Planı (National Plan Of Action For Children) ve Yedinci Beş Yıllık Plan belirtilebilir. Ayrıca Kadın ve Çocuk Gelişimi Bakanlığ amacıyla çocuk bütçeleme yaklaşımından yaralanılmaktadır. Bunun dışında, bakanlık tarafından hazırlanan raporlar düzenli olarak Birleşmiş Milletler Çocuk Haklar1 Komitesi'ne (UN Committee On The Rights Of The Child) gönderilmektedir (Save The Children, 2010: 61).

Birim tarafından ülkede çocuk haklarının gelişimiyle ilgili bir indeks de kullanılmaktadır. $\mathrm{Bu}$ indeksten elde edilen çeşitli veriler analiz edilmekte ve gelecekteki hükümet programlarının belirlenmesinde yol gösterici olarak kullanılmaktadır. $\mathrm{Bu}$ indeksten elde edilen veriler neticesinde, çocuk yardımları açısından yetersiz olan eyaletlerinin tespiti, bu konuda personelin eğitimi, gereken altyapının tesisi ve yeni politikaların belirlenmesi gibi bir dizi adım atılmaktadır (Centre For Child Rights-HAQ, 2011: 11). Ülkenin bu yönüyle pek çok ülkeye örnek teşkil edecek çalışmalar sürdürmekte olduğunu ifade etmek gerekir.

\section{Galler}

Galler, Birleşik Krallık üyesi dört ülkeden biridir. Bu ülkede de çocuklara yönelik bütçeleme anlayışına yönelik faaliyetler sürdürülmektedir. Ülkede bir tür sivil toplum kuruluşu olan Çocukları Koruma Örgütü (Save The Children) tarafindan kamu harcamaları analize tabi tutulmakta ve doğrudan çocuklara yönelik olanlar tespit edilmeye çalışılmaktadır. Bu konuda Örgüt tarafindan rapor hazırlanmakta ve bu rapor çocuklara yönelik yeni politikaların belirlenmesinde rehber niteliği taşımaktadır. Örgüt tarafından ülkedeki çocuklara yönelik doğrudan kamu harcamaları incelenirken, dolaylı kamu harcamaları da ihmal edilmemektedir. Örneğin, 2012'de Gallerli 45.280 ailenin 1sınma masraflarını karşılamada güçlük yaşadığı tespit edilmiştir. Bunun üzerine Örgüt tarafından Birleşik Krallık Hükümetine çağrıda bulunulmuş ve ihtiyaç sahibi ailelerin Ilık Evler Hesab1 (Warm Homes Discount)'ndan maddi destek alabilecekleri ifade edilmiştir. Bunun neticesinde, Birleşik Krallık hükümeti 45,280 ihtiyaç sahibi ailenin bu programından faydalanabileceği ve bu ailelerin elektrik faturalarında düzenli indirim yapılacağı konusunda karar almıştır (BBC News, 2016). Bu örnek düzenleme ise çocuklara yönelik bütçeleme konusunda sivil toplum kuruluşlarının önemini ortaya koyması açısından dikkat çekmektedir. 
Özen O., Bahçe, A. B., Akbey, F.

DEÜ SBE Dergisi, Cilt: 18, Sayl: 3

\section{SONUÇ}

Demokratik yönetim modellerinde toplumsal gereksinimlerin kişi veya sınıf ayrımı yapılmadan karşılanması devlet kurumunun öncelikli amaçlarından biridir. Gerektiğinde devlet, toplum içinde demografik açıdan bazı aksak durumlar ortaya çıktı̆̆ında, bunları gidermeye yönelik politikalar da üstlenmek durumundadır. Nitekim bu amaçla kullanılan en önemli mali araç devlet bütçesi olup, bütçelere sosyal bir anlayışın yerleştirilmesi veya bütçenin sosyal açıdan analiz edilmesi hususları literatürde sosyal bütçeleme kavramını öne çıkarmaktadır. Sosyal bütçelemenin kapsamında yer alan başlıklardan biri de çocuk bütçeleme anlayışıdır.

Birleşmiş Milletler Çocuk Hakları Bildirgesi, yaklaşık 60 yıl önce imzalanmış olup, burada çıkarılacak yasalarda çocuk haklarının öncelikli olarak korunması gerektiği ortaya konmuştur. $\mathrm{Bu}$ bağlamda pek çok ülkede çocuk haklarının korunması veya geliştirilmesine yönelik bir dizi düzenleme getirilmiştir. $\mathrm{Bu}$ tür düzenlemeler pek çok sivil toplum kuruluşu tarafindan da öncelikli olarak takip edilmekte ve çocuk haklarının geliştirilmesine yönelik yeni projeler öngörülmektedir. Sivil toplum kuruluşlarının bu yöndeki faaliyetleri kamu politikaları açısından dikkatleri devlet bütçesi üzerinde yoğunlaştırmakta ve devlet bütçelerinin çocuklara yönelik hizmetler bazında ayrıntılı analizi gerekliliği ön plana çıkmaktadır. Bu tür bir eğilim, kamu politikalarının birincil göstergesi olan devlet bütçelerinin hazırlanma aşamasında çocukların gereksinimlerinin de dikkate alınmasını öncelikli hale getirmektedir.

Öncelikle gelişmiş ülkelerde ilk adımlarının atıldığı "çocuk bütçesi", girişimleri, günümüzde pek çok devlet açısından anımsanmayacak ölçüde uygulanır hale gelmiştir. Nitekim çocuk bütçesine yönelik faaliyet yürütmekte olan çeşitli ülkeler arasından ABD, Vietnam, Ekvador, Güney Afrika, Hindistan, Galler gibi ülkeler çalışma kapsamında ele alınmış ve bu ülkelerdeki uygulama farklılıkları ile elde edilen çıktılara yer verilmiştir. Ülke örneklerinden de anlaşılabileceği üzere herhangi bir toplumda çocuklar diğer toplum bireylerinden farklı özelliklere sahiptir ve daha fazla pozitif ayrıma tabi tutulması gerekmektedir. Öyle ki siyasal anlamda taleplerini doğrudan siyasal karar alıcılara yansitma imkanı olmayan çocukların diğer kesimler gibi baskı ve çıar grubu olma özelliği olmamasından ötürü firsat eşitsizliğine maruz kalma ihtimalleri çok yüksektir. Yani çocuklar diğer toplum kesimlere karşı daha fazla korunmaya ihtiyaç duymakta olup, bunu sağlamak amaciyla devlet bütçeleri etkin bir araç olma özelliği taşımalıdır. Sonuç olarak genç nüfusa sahip olmanın övünç ve avantaj; yaşlı nüfusa sahip olmanın ise ülkeler için sorun olarak görüldügü günümüz dünyasında çocuklara gösterilecek değer aslında bir ülkenin yarınlarına verdiği önemi de yansitmaktadir. 


\section{KAYNAKÇA}

BBC News. (2016). Save the children in wales warns of fuel discount help ignorance, http:// www .bbc.co.uk/news/uk-wales-16400454. (21.01.2016).

Centre For Child Rights-HAQ. (2011). Budget for children (BfC) in the Union Budget 2012-13, www.haqcrc.org. (22.02.2016).

Children and Young People Committee. (2009). Children's budgeting in wales. National assembly for wales. http://www.a ssembly.wales/Laid \%20Documents/CR-LD774 9\%20-\%20Children\%20 and\%20Yo ung\%20 Peo ple\% 20Committee's\%20 Report\%20on\%20Child ren's\%20Budgeting\% 20in\%20Wales-19102009-148251/cr-ld7749-e-English.pdf., (15.01.2016).

Cichon, M., Hagemejer, K. ve W. Scholz. (2001). Social budgeting in transition economies. International Social Security Review. 54 (2-3): 191-215.

Deles, P., Mendoza, R.U. ve G. Vergara. (2010). Social budgeting initiatives and innovations: Insights using a public finance lens. Draft for Discussion, http://www.researchgate.net/profile/Ronald_Mendoza3/publication/228958685_So cial_budgeting_initiatives_and_innovations_Insights_using_a_public_finance_lens /links/0046351c15677d4933000000.pdf., (15.01.2016).

Doytch, N., Gore,R., Hu, D., Joshi, R, Mendoza, R., Murthy, S. ve G. Vergara. (2010). A guide to advancing the rights of children, women and poor families through better public finance policies. UNICEF Social and Economic Policy Working Paper, http://www.childimpact.unicef-irc.org/documents/view /id/69/lang/en., (25.02.2014).

Erkan, B., Şentürk, M., Akbaş, Y.E. ve S. Paksoy. (2012). Dünyada ve Türkiye'de sosyal bütçeleme (cinsiyete duyarlı bütçe) yaklaşımı. Uluslararası İktisadi ve İdari Íncelemeler Dergisi, 5 (9): 85-105.

Ortiz, I., Chai, J., Cummins, M. ve G. Vergara. (2010). Prioritizing expenditures for a recovery for all. UNICEF Social and Economic Policy Working Paper, http://www.unicef.org/socialpolicy/files/Prioritizing_Expenditures_for_a Recovery_for_All_October_11_final.pdf, (25.02.2014).

Ortiz, I., Chai, J. ve M. Cummins. (2011a). Austerity measures threaten children and poor households: Recent evidence in public expenditures from 128 developing countries. UNICEF Social and Economic Policy Working Paper, http://www.unicef.org/socialpolicy/files/Austerity_Measures_Threaten_Children. pdf, (25.02.2014).

Ortiz, I., Chai, J. ve M. Cummins. (2011b). Identifying fiscal space: Options for social and economic development for children and poor households in 182 countries. UNICEF Social and Economic Policy Working Paper, http://www.childimpact.unicef-irc.org/documents/view/id/132/lang/en., (25.02.2014). 
Özen O., Bahçe, A. B., Akbey, F.

DEÜ SBE Dergisi, Cilt: 18, Sayl: 3

Pantin, D., Ramjattan D. ve J. Francis. (2010). Child responsive budgeting: The case of Trinidad and Tobago. United Nations Children's Fund (UNICEF), http://www.unicef.org/socialpolicy/files/Child_Budgeting_Paper_15Nov01.pdf., (25.02.2014).

Save The Children. (2010). Budget for children analysis. Save The Children Sweden Regional Office For South And Central Asia. www.sca.savethechildren.se, (25.02.2014).

Scholz, W., Cichon, M. ve H. Krzysztof. (2000). Social budgeting. Geneva: International Labour Office/International Social Security Association Press.

Shore, R. ve Shore, B. (2009). Kids count indicator brief: Reducing the child poverty rate. The Annie E. Casey Foundation. http://www.aecf.org/m/resourcedoc/ AECF-KCReducing childpoverty-2009.pdf, (25.01.2016).

The African Child Policy Forum. (2011). Budgeting for children in AfricaRhetoric-Reality and the scorecard. www.africanchildforum.org, (11.01.2016).

UNICEF. (2014). Every child counts. Revealing disparities, advancing children's rights. http://www.unicef.org/sowc2014/numbers/documents/english/ SOWC2014_In\%20Numbers_28\%20Jan.pdf, (25.01.2016).

UNICEF Innocenti Research Centre. (2007). Reforming child law in South Africa: Budgeting and implementation planning. United Nations Children's Fund (UNICEF), http://www.unicef.org/southafrica/SAF_resources_refchildlaw.pdf, (12.01.2016). 